\title{
A Very Solid Fuel: Ferrous Iron Oxide as a Geochemical Energy Source
}

\author{
John W. Halloran \\ Department of Materials Science and Engineering, University of Michigan, Ann Arbor, USA \\ Email: peterjon@umich.edu \\ Received 14 January 2015; accepted 2 February 2015; published 5 February 2015 \\ Copyright (C) 2015 by author and Scientific Research Publishing Inc. \\ This work is licensed under the Creative Commons Attribution International License (CC BY). \\ http://creativecommons.org/licenses/by/4.0/

c) (7) Open Access

\begin{abstract}
Ferrous iron oxides, present in abundant minerals such as olivines, can be oxidized to ferric iron oxide to produce more energy per unit oxygen than carbon and hydrogen. These "geofuels" are essentially inexhaustible. Energy might be extracted from geofuels by using the ferrous iron oxide to reduce fluids for use in a fuel cell. Water can be reduced by geofuels, producing hydrogen fuel. Ferrous iron oxide containing rocks are abundant, but diluted with inert oxides. Exploiting them requires new technologies to extract the energy and handle the oxidized mineral residues.
\end{abstract}

\section{Keywords}

Solid Fuel, Geofuel, Olivine

\section{Introduction}

Oxidation-reduction (redox) reactions convert chemically stored energy into useful heat or work, by the reaction of a chemically reduced substance with a chemically oxidized substance (a redox pair). Oxygen is usually the oxidant in the redox pair. Oxygen is abundant in the atmosphere and has no monetary cost. Attention is usually focused on the reduced material of the redox pair, which is the fuel. Fuels are relatively scarce and costly. Enormous effort and expense are devoted to the production of coal and other fossil fuels. The great convenience of coal is that it is available in many parts of the world as large deposits, the result of millions of years of accumulation of fossil carbon. This has made coal a preferred solid fuel for the past several centuries. But the mining of coal causes great environmental damage to land and water. Burning coal burdens the atmosphere by releasing fossil carbon that had been accumulated over millions of years as carbon dioxide greenhouse gas. The concentration of carbon dioxide in the atmosphere has risen in recent decades due to the difference between the rate at which $\mathrm{CO}_{2}$ is released and the ability of the natural carbon dioxide cycle to remove it from the atmosphere. Much effort is currently underway in a global effort to artificially sequester carbon dioxide. This is a very diffi- 
cult challenge, but appears to be necessary if we are to prevent further increase in atmospheric $\mathrm{CO}_{2}$, while we continue to oxidize fossil carbon. It is useful to think beyond the use of fossil carbon as the reduced substance for energy conversion by redox reactions. Instead of coal as a solid fuel, perhaps we can consider the use of a different kind of solid fuel-the chemically reduced minerals in certain rocks. Can these hard rocks be used as a very solid fuel?

Our planet consists of a thin layer of an oxidizing atmosphere with a rocky crust that contains a large fraction of chemically reduced substances. Much of the chemically reduced substances involve compounds of ferrous iron oxide $\mathrm{Fe}(\mathrm{II}) \mathrm{O}$, combined as rock-forming minerals. As these reduced compounds could be part of a useful redox pair, we might consider them to be geochemical energy resources, or "geofuels" to react with oxygen. If it were possible to extract useful energy from the difference in the redox potential of the reduced rocks and the oxidizing air, we potentially could exploit a massive energy resource that does not involve fossil carbon. Atmospheric oxygen is the accumulated residue of photosynthesis [1]. It might be considered a fossil oxidant. Converting energy by geo-fuel oxidation would also involve fossil resources, but in this case "fossil oxygen". There is a very large supply of oxygen stored in the atmosphere, around $10^{21}$ grams, so the available resource is quite large. While the atmosphere is large, it is only a tiny fraction of the mass of the Earth. The amount of reduced compounds in the outer crust greatly exceeds the oxygen in the atmosphere. In this regard, the oxidant is relatively scarce compared to the reduced material.

Rocky geofuel is abundant to the point of being essentially inexhaustible. Under the right conditions, it should be possible to obtain a great deal of useful energy by reacting the reduced minerals in the crust with oxygen in the air. Ferrous oxide-containing rocks would be very unconventional fuels. Exploiting them would require the development of new technology, and certainly would be very costly. But the massive scale of the available resource perhaps justifies the effort. Of course, rocks cannot be burned like coal to liberate heat. Other energy conversion methods will be required. Confronted with the well-known difficulties of coal, and attracted by the great abundance of geofuels, it is worthwhile to consider the possibilities. This paper explores this concept, and considers the technologies that may be useful to obtain heat or work by oxidation of geo-fuels.

\section{Geofuels}

The term "fuel" typically connotes something that can be burned, like the solid fuels coal and wood or gas and oil. But let us generalize beyond that. A fuel does not have to burn to be useful for energy conversion. Fuel cells convert chemical energy to electrical energy by electrochemical oxidation, not combustion. Rather than think of the reduced species as fossil hydrocarbons, consider instead the oxidation of reduced minerals as geofuels. Let us emphasize ferrous iron oxide compounds as the geofuel, and consider some it its attributes.

\subsection{Ferrous Iron Is a Rich Fuel}

We normally think of carbon and hydrogen as rich fuels, because of the larger enthalpy difference between the reduced substances ( $\mathrm{C}$ and $\mathrm{H}_{2}$ ) and the oxidized substances $\left(\mathrm{CO}_{2}\right.$ and $\left.\mathrm{H}_{2} \mathrm{O}\right)$. But note that there is also a large enthalpy difference between ferrous iron oxide $\mathrm{Fe}(\mathrm{II}) \mathrm{O}$ and ferric iron oxide $\mathrm{Fe}(\mathrm{III})_{2} \mathrm{O}_{3}$ (hematite). This can be quantified by the standard enthalpy change of the oxidation reaction at standard temperature $(298 \mathrm{~K})$ and pressure $(1 \mathrm{~atm})$. Consider the four reactions in Table 1, for oxidation of hydrogen, carbon, methane and ferrous iron oxide. These reactions are written on the basis of one mole of $\mathrm{O}_{2}$ because this is convenient for reactions with different stoichiometries. The table compares the standard enthalpies of these reactions. The reaction of

Table 1. Enthalpy of oxidation of fuels.

\begin{tabular}{|c|c|c|c|}
\hline Fuel & & Reaction & $\begin{array}{c}\text { Standard enthalpy change } \\
\text { per mole of oxygen }\end{array}$ \\
\hline Hydrogen & Reaction (1) & $2 \mathrm{H}_{2}+\mathrm{O}_{2}=2 \mathrm{H}_{2} \mathrm{O}$ & $-484 \mathrm{~kJ} /$ mole $\mathrm{O}_{2}$ \\
\hline Carbon & Reaction (2) & $\mathrm{C}+\mathrm{O}_{2}=\mathrm{CO}_{2}$ & $-393 \mathrm{~kJ} /$ mole $\mathrm{O}_{2}$ \\
\hline Methane & Reaction (3) & $0.5 \mathrm{CH}_{4}+\mathrm{O}_{2}=0.5 \mathrm{CO}_{2}+\mathrm{H}_{2} \mathrm{O}$ & $-405 \mathrm{~kJ} / \mathrm{mole} \mathrm{O}_{2}$ \\
\hline Ferrous oxide & Reaction (4) & $4 \mathrm{FeO}+\mathrm{O}_{2}=2 \mathrm{Fe}_{2} \mathrm{O}_{3}$ & $-570 \mathrm{~kJ} / \mathrm{mole} \mathrm{O}_{2}$ \\
\hline
\end{tabular}


four moles of $\mathrm{FeO}$ with one mole of oxygen to produce two moles of hematite releases $570 \mathrm{~kJ}$ of heat. This is substantially larger than Reaction (1) for hydrogen, which releases $484 \mathrm{~kJ}$ of heat per mole of oxygen, or Reaction (2) for carbon, which releases $393 \mathrm{~kJ}$ per mole of oxygen. Methane is included to compare Fe(II)O with natural gas.

Notice that the standard enthalpy for oxidation of ferrous iron oxide is about $40 \%$ larger the enthalpy of oxidation of carbon or methane. By this measure, ferrous iron oxide is potentially a richer fuel than carbon. No carbon dioxide greenhouse gas is directly created by the oxidation of ferrous iron oxide to ferric iron oxide compounds, so it is potentially less damaging to the atmosphere.

Only the enthalpy of the reaction appears in Table 1, so it only compares the thermodynamics of the redox reaction. The rate of the reaction, or the kinetics, is not considered in the table, and is not directly related to the thermodynamics. The rate of oxidation of ferrous iron oxide rocks will certainly be much slower than the oxidation of carbon or hydrogen. It is technically convenient that redox reactions for our familiar fossil fuels have very fast oxidation kinetics. The fast reaction rates are enabled by the fact that the redox reactions occur in the gas phase with methane, hydrogen, or the volatiles from coal. Heat is rapidly liberated by combustion flames in conventional burners, and almost all energy from fossil fuels are extracted by combustion, and is used to drive heat engines. The oxidation of solid $\mathrm{Fe}(\mathrm{II}) \mathrm{O}$ to solid $\mathrm{Fe}(\mathrm{III})_{2} \mathrm{O}_{3}$ involves much slower gas-solid reactions. Ferrous iron oxide will not burn in a flame, so other means are required to extract the enthalpy.

\subsection{Ferrous Iron Is Abundant}

There is a great deal of ferrous iron oxide in the Earth's crust. About $5 \mathrm{wt} \%$ of outer crust consists of ferrous iron oxides [2] so the available quantity of reduced iron oxides is enormous. Ferrous iron oxide is found in many rocks, including basalts. Basaltic rocks are abundant and ubiquitous as about $10 \%$ of the continents and much of the ocean floor are basalts [3]. The amount of ferrous iron oxide compounds is essentially inexhaustible. But $\mathrm{FeO}$ is not present as a free compound. It is combined with silicon dioxide, magnesium oxide, and other compounds. Much of the $\mathrm{FeO}$ is present as the silicate compound $\mathrm{Fe}_{2} \mathrm{SiO}_{4}$ fayalite that is further combined with $\mathrm{Mg}_{2} \mathrm{SiO}_{4}$ (forsterite) in the mineral olivine $\left[\mathrm{Mg}_{1-\mathrm{x}} \mathrm{Fe}(\mathrm{II})_{\mathrm{x}}\right]_{2} \mathrm{SiO}_{4}$, which can also be written as a combination of forsterite (FO) and fayalite (FA) as $\mathrm{FO}_{1-\mathrm{x}} \mathrm{FA}_{\mathrm{x}}$. The fayalite fraction in olivines varies widely, from $\mathrm{x}=0.05$ to about $\mathrm{x}=0.20$. A typical olivine, with a composition $\mathrm{FO}_{0.9} \mathrm{FA}_{0.1}$ has less than 7 mole\% $\mathrm{Fe}(\mathrm{II}) \mathrm{O}$ fuel and 93\% inert oxides. So while ferrous iron oxides are abundant, they are not highly concentrated so the oxidizable fuel component $(\mathrm{Fe}(\mathrm{II}) \mathrm{O})$ is diluted by inert constituents $\left(\mathrm{MgO}\right.$ and $\left.\mathrm{SiO}_{2}\right)$. Iron-containing minerals are present in much higher concentration in iron ore deposits, but most iron ores contain compounds of ferric iron oxides, so are already fully oxidized and are not useful as a fuel.

The resource potential of olivine rocks ranging from iron rich $\mathrm{FO}_{0.8} \mathrm{FA}_{0.2}$ to iron-lean $\mathrm{FO}_{0.95} \mathrm{FA}_{0.05}$ might be compared with conventional measures for fossil fuel resources. Hydrocarbon resources are characterized by many parameters, including the "total organic carbon" TOC, which is the weight percent of hydrocarbon present in the source rock. Let us compare olivines with shale gas. The value for the TOC in a prominent North American shale gas reservoir, Marcellus Shale, is $1.57 \mathrm{wt} \%$ total organic carbon [4]. Of course ferrous rocks have no carbon, and do not have a TOC value. Instead we must define a related quantity. Consider a "gravimetric energy value" (GEV) of hydrocarbons in their source rock, expressed as available enthalpy from oxidation per gram of the source rock ( $\mathrm{kJ} / \mathrm{g}_{\text {source rock }}$ ). The hydrocarbon in shale gas is mostly methane, so we use the standard enthalpy of oxidation for methane, which is $405 \mathrm{~kJ} / \mathrm{mole}_{2}$ or $50.6 \mathrm{~kJ} / \mathrm{g} \mathrm{CH}_{4}$. Using the TOC value of the shale, we can obtain the gravimetric energy value GEV in units of $\mathrm{kJ} / \mathrm{g}_{\text {source rock. }}$. These are displayed in Table 2 for Marcellus Shale, which is being vigorously developed in North America with hydrofracturing. We can convert that to a "volumetric energy value" VEV using the density of the source rock, which we might assume to be $2.5 \mathrm{~g} / \mathrm{cm}^{3}$, to obtain values of the VEV in units of $\mathrm{kJ} / \mathrm{cm}_{\text {source rock }}^{3}$. These also are displayed in Table 2.

Now consider the gravimetric and volumetric energy values for olivines, using a similar argument.

The molar energy of oxidation for $\mathrm{Fe}(\mathrm{II}) \mathrm{O}$ to hematite is $570 \mathrm{~kJ} / \mathrm{moleO}_{2}$. But the $\mathrm{Fe}(\mathrm{II}) \mathrm{O}$ is combined with silicon dioxide in fayalite $\mathrm{Fe}(\mathrm{II})_{2} \mathrm{SiO}_{4}$, and the energy of oxidation $286 \mathrm{~kJ} /$ mole Fayalite (FA). For an olivine with forsterite mole fraction $F_{O}$ the molar energy per mole of olivine is $(286 \mathrm{~kJ} / \mathrm{mol} \mathrm{FA})(1-\mathrm{FO})$ mole $\mathrm{FA} / \mathrm{mol}_{\text {olivine }}$. This is in terms of molar quantities. To convert to gravimetric energy value, we use the molecular weights of Forsterite $\mathrm{Mg}_{2} \mathrm{SiO}_{4}$ and Fayalite $\mathrm{Fe}_{2} \mathrm{SiO}_{4}$ is $230.9 \mathrm{~g} / \mathrm{mol} \mathrm{FA}$. For an olivine of composition FA, the GEV can be calculated as [286FA/(140.7 + 63.2 FA)] kJ/g olivine. Table 2 lists the GEV for three olivine compositions, 
Table 2. Energy value of shale and olivine.

\begin{tabular}{cccc}
\hline Resource & $\begin{array}{c}\text { TOC-Total Organic } \\
\text { Carbonas weight percent }\end{array}$ & $\begin{array}{c}\mathrm{GEV} \text {-Gravimetric } \\
\text { Energy Value }\end{array}$ & $\begin{array}{c}\mathrm{VEV} \text {-Volumetric } \\
\text { Energy Value }\end{array}$ \\
\hline Marcellous shale & $\mathrm{TOC}=1.57 \%$ & $0.8 \mathrm{~kJ} / \mathrm{g}_{\text {source rock }}$ & $2.0 \mathrm{~kJ} / \mathrm{cm}_{\text {source rock }}^{3}$ \\
Olivine $\mathrm{FO}_{0.95} \mathrm{FA}_{0.05}$ & $\mathrm{TOC}_{\mathrm{VE}}=0.26 \%$ & $0.10 \mathrm{~kJ} / \mathrm{g}_{\text {olivine }}$ & $0.33 \mathrm{~kJ} / \mathrm{cm}_{\text {olivine }}^{3}$ \\
Olivine $\mathrm{FO}_{0.9} \mathrm{FA}_{0.10}$ & $\mathrm{TOC}_{\mathrm{VE}}=0.53 \%$ & $0.20 \mathrm{~kJ} / \mathrm{g}_{\text {olivine }}$ & $0.67 \mathrm{~kJ} / \mathrm{cm}_{\text {olivine }}^{3}$ \\
Olivine $\mathrm{FO}_{0.80} \mathrm{FA}_{0.20}$ & $\mathrm{TOC}_{\mathrm{VE}}=1.0 \%$ & $0.37 \mathrm{~kJ} / \mathrm{g}_{\text {olivine }}$ & $1.28 \mathrm{~kJ} / \mathrm{cm}_{\text {olivine }}^{3}$ \\
\hline
\end{tabular}

ranging from iron-poor $(\mathrm{FA}=0.05)$ to iron-rich $(\mathrm{FA}=0.20)$. Note that these values are about one tenth of the GEV value for gas-bearing shales, but considering that olivines are much more abundant globally, it still represents a resource of considerable potential. The density of olivine can be used to convert the GEV to volumetric energy value. The density of olivine depends on the composition or fayalite fraction FA [as $(3.22+1.17$ FA) $g_{\text {olivine }} / \mathrm{cm}^{3}$ ]. The VEV values for three olivine compositions are in Table 2. Depending on the iron concentration of the olivine, the volumetric energy value for olivine is about $15 \%-60 \%$ or the VEV of the Marcellus Shale. The energy reserves of the Marcellus Shale are being vigorously exploited in North America. Perhaps olivines could be attractive, particularly iron-rich olivine.

It is also possible to compute an "equivalent" TOC for olivines. Of course the TOC is the total organic carbon, which is strictly only applicable for a hydrocarbon fuel. A quantity related to the TOC value would be useful. Consider a "volume-equivalent TOC", or TOC $\mathrm{VE}_{\mathrm{E}}$, which indicates the energy potential of an olivine, after oxidation of the ferrous iron oxide, compared to the energy potential of the same volume of a gas-bearing source rock. The volume equivalent $\mathrm{TOC}_{\mathrm{VE}}$ for the three olivine compositions are obtained by comparing the numbers in Table 2 for the source rock for shale gas and for ferrous iron oxide oxidation. An olivine of composition $\mathrm{FO}_{0.8}$ has a $\mathrm{TOC}_{\mathrm{VE}}$ that is about $60 \%$ of the Marcellus Shale. This value is lower, but one might consider the olivine potential to be roughly comparable to shale gas. As olivine is a very common rock, present in many locations around the world, the combination of reasonable energy value with great abundance might make the olivine energy resource appear rich enough to develop.

Table 2 compares the energy values of olivines with gas-bearing shales. But exploiting these resources will be quite different. Producing natural gas from shale involves drilling and hydrofracturing technologies that are highly sophisticated versions of traditional gas production techniques. The product is natural gas, a well-established fuel with a well-developed market. Producing energy from ferrous iron oxide geofuels will present difficult challenges. When considering the various challenges of geofuels, it might be useful to compare them with the scale of energy production by other means. It is easy to use refined petroleum products, but deep-water drilling and unconventional oil are technologically difficult and very costly. Coal is easy to burn, but carbon dioxide capture and sequestration will be difficult and expensive. The nuclear power in fission reactors supplies a significant fraction of electrical needs, but long-term solutions to radioactive wastes have not yet been found. The technology involved for producing energy by conventional means is sophisticated, and it has been intensively pursued for around the globe for many years. The great promise of controlled fusion of hydrogen isotopes motivates highly sophisticated science and technology. Half a century of investment of money and intellectual effort in nuclear fusion has not produced a single joule of commercial energy, but still the programs continue around the world. Energy production is a hard problem, and obtaining novel energy sources will be difficult. Some of the challenges for exploiting geofuels are presented in the following sections, with speculations on possible engineering approaches.

Note that the suggestion of olivine as a geofuel is not the first time that hard rocks like basaltic rocks have been considered for use in global-scale energy technologies. Mineral carbonization [3] [5] is a prominent strategy for sequestration of carbon dioxide. One of the mineral carbonization approaches is to react the magnesium oxide component of forsterite in olivines with carbon dioxide to form solid magnesium carbonate. Strategies have been explored to carbonate the olivines in-situ in hydrofractured basalts [6], where the reaction occurs deep underground in ambient conditions and the product minerals remain in place. Other approaches involve mining basaltic olivine and pulverizing the rock to a fine powder, for reaction with carbon dioxide $e x$-situ on the surface in large industrial plants [7]. Reaction conditions are similar to industrial processing of minerals, and the product remains on the surface. The technoeconomics of mineral carbonation have been considered with a life cycle 
analysis [8]. These mineral carbonation studies are relevant to the case of geofuel oxidation, as many of the unit operations are similar for both in-situ and ex-situ reactions. Some of the concepts for geofuel exploitation are analogues to the mineral carbonation ideas.

\section{Challenges of Exploiting Geofuels}

The richness of the resource and enormous quantity of the resource makes it worthy of attention. Ferrous rocks are abundant rich fuels, but exploiting them poses significant engineering challenges. Basaltic rocks that contain olivine are very hard. The ferrous iron will oxidize with very slow kinetics, and are not combustible. Oxidation leaves a very large volume of residue, consisting of ferric iron and other constituents. These issues create difficult problems, but practical solutions can be found.

\subsection{Rocks Do Not Burn}

Fossil hydrocarbons have the great convenience of rapid oxidation, so they can burn to release the enthalpy very rapidly to created hot combustion products to drive a heat engine to generate electricity. There is no experimental data for hot dry oxidation of fayalite in olivines. Presumably the reaction would form hematite and silicon dioxide, with unreacted magnesium silicate:

$$
\left[\mathrm{Mg}_{1-\mathrm{x}} \mathrm{Fe}(\mathrm{II})_{\mathrm{x}}\right]_{2} \mathrm{SiO}_{4}+\mathrm{x} / 2 \mathrm{O}_{2}=\mathrm{xFe}(\mathrm{III})_{2} \mathrm{O}_{3}+\mathrm{xSiO}_{2}+(1-\mathrm{x}) \mathrm{Mg}_{2} \mathrm{SiO}_{4}
$$

Reaction (5)

Dry oxidation of pulverized ferrous rock might occur at a practical rate at elevated temperature, if the particle size were small enough. The adiabatic temperature rise can be calculated from the enthalpy of the oxidation and the heat capacity of the products and the reactants. The enthalpy for Reaction (4) in Table 1 for the reaction of $\mathrm{Fe}(\mathrm{II}) \mathrm{O}$ itself, would suffice to increase the temperature of the iron oxides by about $1190^{\circ} \mathrm{C}$. For pure $\mathrm{Fe}(\mathrm{II}) \mathrm{O}$, this might be high enough for a self-sustaining reaction, with excess heat available for energy conversion. However, in an olivine the ferrous iron is diluted by non-reactive magnesium oxide and silicon dioxide. Less Fe(II)O is available for reaction, and the inert compounds must be heated, so the adiabatic temperature rise is much less. For an iron-rich olivine $\left[\mathrm{Mg}_{0.8} \mathrm{Fe}(\mathrm{II})_{0.2}\right]_{2} \mathrm{SiO}_{4}$ the adiabatic temperature rise is only about $360^{\circ} \mathrm{C}$. So the reaction cannot produce useful heat. Exploiting ferrous iron fuel requires some different approaches.

\subsection{Redox Fluids for Fuel Cells}

A rocky solid fuel is not convenient for a fuel cell, but perhaps a redox fluid could be developed which is recharged by reaction with the ferrous iron oxide. Suitable redox fluids might be aqueous sulfate solutions $\left(\mathrm{SO}_{4}^{2-}\right)$, which are reduced to sulfites $\left(\mathrm{SO}_{3}^{2-}\right)$, or nitrate solutions $\left(\mathrm{NO}_{3}^{-}\right)$, reduced to nitrites $\left(\mathrm{NO}_{2}^{-}\right)$, phosphates, or other systems that could be developed. The redox fluid in its reduced state could be oxidized in a fuel cell with atmospheric oxygen to produce electricity. Here the reduced redox fluid acts as the fuel for the electrochemical cell. In the next step, the oxidized redox fluid could be subsequently reacted with ferrous rocks to return it its reduced state, and replenish the redox fuel. This could be conducted as a repeating cycle of oxidation and reduction of the redox fluid. The replenishing reaction could by done $e x$-situ, bringing the ferrous iron compounds to the surface where they are reacted with the redox fluid in an industrial reactor. Alternatively, the fluid/rock reaction could be done in-situ, by bringing the oxidized redox into the source rock, probably after hydrofracturing to increase the reaction interface. The solid reaction products, such as the ferric iron compounds and inert compounds, would remain in place for the in-situ reaction.

The kinetics of this solid-liquid reaction will depend on the surface area, and are likely to be slow. Slow kinetics imply a long residence time to replenish the redox fluid. A long residence time implies a large inventory of reaction media, which would increase the costs for $e x$-situ reactions. For the in-situ version, it might imply that the oxidized redox fluid would be injected some months before the replenished (reduced) redox fluid was extracted. If the oxidation reaction only takes place at the solid/liquid interface, the reaction may be self-limiting, although for olivine carbonation, the volume change of the reaction causes reaction-driven cracking that exposes fresh interfaces [9].

\subsection{Hydrogen Production and Chemical Looping}

A working fluid could be reacted with ferrous rock to oxidize it to ferric rock and produce a more convenient 
secondary fuel from the working fluid. Hydrogen from water reduction would be a very convenient working fluid. Steam might be reduced to hydrogen, as with Reaction (6).

$$
2 \mathrm{FeO}+\mathrm{H}_{2} \mathrm{O}=>\mathrm{Fe}_{2} \mathrm{O}_{3}+\mathrm{H}_{2}
$$

Reaction (6)

The hydrogen so produced could be used as a conventional fuel in a fuel cell or heat engine. If conducted on hot dry rock with steam, Reaction (6) is a version of the steam-iron reaction that was formerly a classical manufacturing method for hydrogen [10], where hot steam was reacted with hot FeO. A more recent variation [11] employed chemical looping in an industrial reactor, producing magnetite $\mathrm{Fe}(\mathrm{II}) \mathrm{Fe}(\mathrm{III})_{2} \mathrm{O}_{4}$. This might be done by reacting hot ferrous rock with steam, producing hot ferric rock.

\subsection{Artificial Serpentinization for Hydrogen Production}

A reaction similar to Reaction (6) occurs naturally in the deep ocean, where ferrous iron oxide rocks react with water to liberate hydrogen. It is part of the process that converts reduced oxide mineral olivine to hydrous serpentine. The simplified reaction, from Frost [12] can be idealized as:

$$
2(\mathrm{FeO})_{\text {rock }}+\mathrm{H}_{2} \mathrm{O}=\left(\mathrm{Fe}_{2} \mathrm{O}_{3}\right)_{\text {rock }}+\mathrm{H}_{2}
$$

Reaction (7)

where free hydrogen is reduced by ferrous iron $\mathrm{Fe}(\mathrm{II})$ as the iron is oxidized to ferric iron Fe(III). In this simple case, $\mathrm{FeO}$ is component of olivine and ferric iron is a component of iron serpentine and magnetite, as in Reaction (8):

$$
6 \mathrm{Fe}_{2} \mathrm{SiO}_{4}+7 \mathrm{H}_{2} \mathrm{O}=3 \mathrm{Fe}_{3} \mathrm{Si}_{2} \mathrm{O}_{5}(\mathrm{OH})_{4}+\mathrm{Fe}_{3} \mathrm{O}_{4}+\mathrm{H}_{2}
$$

Reaction (8)

Considering the magnesium silicate in the olivine, and the production of magnesium serpentine and magnesium hydroxide, a more complex reaction might be Reaction (9) for a Fo ${ }_{90}$ olivine composition:

$$
30\left(\mathrm{Mg}_{0.9} \mathrm{Fe}_{0.1}\right)_{2} \mathrm{SiO}_{4}+41 \mathrm{H}_{2} \mathrm{O}=15 \mathrm{Mg}_{3} \mathrm{Si}_{2} \mathrm{O}_{5}(\mathrm{OH})_{4}+9 \mathrm{Mg}(\mathrm{OH})_{2}+2 \mathrm{Fe}_{3} \mathrm{O}_{4}+2 \mathrm{H}_{2} \quad \text { Reaction (9) }
$$

In fact, the reactions are much more complicated. Under conditions relevant for hot rock and seawater at depth depends on the water chemistry and mineral compositions. The natural reaction and laboratory simulation has been recently reviewed by McCollom [13] in the context of hydrocarbon production in the deep subsurface. The tendency of ferrous iron $\mathrm{FeO}$ to combine as a ferrous hydroxide $\left[\mathrm{Mg}_{1-\mathrm{x}} \mathrm{Fe}(\mathrm{II})_{\mathrm{x}}\right](\mathrm{OH})_{2}$ or other minerals, also depends on $\mathrm{pH}$ and dissolved $\mathrm{H}_{2}$ in water. The kinetics the serpentization reaction is sensitive to other compounds, such as aluminum [14]. Serpentinzation kinetics would be particularly important if the process were to be exploited as an industrial scale energy source [14].

The details of industrial scale serpentinization are not yet known, but there should be conditions that favor a high yield of hydrogen. The resource-ferrous iron oxide and water-are present. The engineering task is to exploit the reaction to generate geochemical hydrogen as an industrial fuel. Research on reaction engineering could be aimed at accelerating the kinetics and reaction engineering, either bringing the ferrous rock to a reactor (industrial serpentinization) or conducting the reaction deep underground with subsequent capture of hydrogen as a gas (artificial in-situ serpentinization).

\section{5. "Ash" from Oxidation of Geofuels}

If we consider ferrous rocks as geofuel, we perhaps should consider the residual material after oxidation as an "ash". Ferrous iron containing rocks have a great deal of ash, as a solid residue of inert compounds and ferric iron compounds. We must compare this to hydrocarbon fossil fuels, which have very little solid residue. For example, burning a relatively high-ash coal (10 wt\% ash) to produce $1 \mathrm{~kJ}$ of heat leaves a solid residue of only $0.003 \mathrm{gm}$ of solid ash (but of course most of the mass forms $\mathrm{CO}_{2}$ gas). For such a coal, the residual solid per unit heat is $0.003 \mathrm{gm} / \mathrm{kJ}$. For the simple Reaction (4) involving simple $\mathrm{Fe}(\mathrm{II}) \mathrm{O}$ being oxidized to hematite $\mathrm{Fe}(\mathrm{III})_{2} \mathrm{O}_{3}$, the residue per unit heat is $1.18 \mathrm{~g} / \mathrm{kJ}$. FeO is not present in isolation. For oxidation of fayalite, with residue ferric serpentine and magnetite by Reaction (7), the residue is $5.4 \mathrm{~g} / \mathrm{kJ}$. Using Reaction (8) for olivine of composition $\mathrm{Fo}_{90}$, the residue is $11.1 \mathrm{~g} / \mathrm{kJ}$, with residue being Mg-serpentine, brucite, and magnetite. Fossil hydrocarbons burn up into vapors. Rocky geofuels do not.

If the oxidation of the geofuel could by conducted in-situ, by artificial serpentization or reaction with a redox fluid, the solid residue is perhaps not a problem as it remains deep underground. If the geofuel is oxidized 
ex-situ, in an industrial reactor, there is an enormous volume of solid residue. The solid residue could be a large disposal problem. On the other hand, the residue could be used to remediate the quarries from which the ferrous geofuel was mined. It could be used to fill the holes created when the geofuel was extracted.

Alternately, the residue could by exploited as an infrastructure material. Much of the infrastructure is build out of rocks. Concrete is an artificial rock with the convenient property of changing from a fluid slurry into a solid. A great deal of quarried aggregate is used to produce concrete. The global consumption of concrete is about 12 billion tons/year, with most of the mass consisting of aggregate. Perhaps geofuel residue could be developed as an aggregate.

\section{Conclusions-Potential and Challenges of Ferrous Iron Oxide Rock as a Solid Fuel}

Ferrous iron oxides in common minerals have a potential to produce useful energy by oxidizing the iron to ferric oxide. Figured on a per mole of oxygen basis, $\mathrm{Fe}(\mathrm{II}) \mathrm{O}$ is $40 \%$ richer fuel than carbon or methane. These compounds are very abundant in the crust, representing an inexhaustible source of fuel for oxidation reactions. But the $\mathrm{Fe}(\mathrm{II}) \mathrm{O}$ is always combined with a large quantity of inert oxides, such as magnesium oxide and silicon dioxide in olivine rocks. So, ferrous iron oxides are abundant, but not highly concentrated. On the basis of energy per volume of source rock, olivines have between $16 \%$ and $60 \%$ of the potential as the gas in the Marcellus Shale.

The energy cannot be liberated by burning, but requires the development of electrochemical methods, or the conversion of the solid ferrous iron oxide to a more convenient fuel. These reactions could be conducted underground, or could be conducted in industrial plants. Ferrous iron oxide can reduce water to generate hydrogen fuel, by the dry steam-iron reaction or by reaction with liquid water as in the natural process that forms the mineral serpentine from olivine. Ferrous ion oxide geofuels will have a very large residue of after oxidation. This oxidized residue could be a solid waste problem, or could be used as an infrastructural aggregate after development of suitable forms.

Ferrous iron oxide in rocks could be a new type of solid fuel-geofuel. But new technologies must be developed to extract the energy in this very solid fuel. The massive size of the resource makes exploiting geofuels a worthy technological challenge.

\section{References}

[1] Lyons, T.W., Reinhard, C.T. and Planavsky, N.J. (2014) The Rise of Oxygen in Earth’s Early Ocean and Atmosphere. Nature, 506, 307-315. http://dx.doi.org/10.1038/nature13068

[2] Hawkesworth, C.J. and Kemp, A.I.S. (2006) Evolution of the Continental Crust. Nature, 443, 811-817. http://dx.doi.org/10.1038/nature05191

[3] Gilason, S.R. and Oelkers, E.H. (2014) Carbon Storage in Basalt. Science, 344, 373-374. http://dx.doi.org/10.1126/science.1250828

[4] Clarkson, C.R., Solano, N., Bustin, R.M., Bustin, A.M.M., Chalmers, G.R.L., He, L., Melnichenko, Y.B., Radlinski, A.P. and Blach, T.P. (2013) Pore Structure Characterization of North American Shale Gas Reservoirs Using USANS/ SANS, Gas Absorption, and Mercury Intrusion. Fuel, 103, 606-616. http://dx.doi.org/10.1016/j.fuel.2012.06.119

[5] Power, I.M., Harrison, A.L., Dipple, G.M., Wilson, S.A., Keleman, P.B., Hitch, M. and Southam, G. (2013) Carbon Mineralization: From Natural Analogues to Engineered Systems. Reviews in Mineralogy and Geochemistry, 77, 305360. http://dx.doi.org/10.2138/rmg.2013.77.9

[6] Matter, J.M. and Keleman, P.R. (2009) Permanent Storage of Carbon Dioxide in Geological Reservoirs by Mineral Carbonation. Nature Geoscience, 2, 837-841. http://dx.doi.org/10.1038/ngeo683

[7] Kwon, S. (2011) Mineralization for $\mathrm{CO}_{2}$ Sequestration Using Olivine Sorbent in the Presence of Water Vapor. Ph.D. Dissertation, Georgia Institute of Technology.

[8] Giannoulakis, S., Volkhart, L. and Bauer, C. (2014) Life Cycle and Cost Assessment of Mineral Carbonation for Carbon Capture and Storage in European Power Generation. International Journal of Greenhouse Gas Control, 21, 140157. http://dx.doi.org/10.1016/j.ijggc.2013.12.002

[9] Kelemen, P.B. and Hirth, G. (2012) Reaction-Driven Cracking during Retrograde Metamophism: Olivine Hydration and Carbonation. Earth and Planetary Science Letters, 345-348, 81-89. http://dx.doi.org/10.1016/j.epsl.2012.06.018

[10] Gupta, R.B. (2008) Hydrogen Fuel: Production, Transport Storage. CRC Press, Boca Raton, 61. 
http://dx.doi.org/10.1201/9781420045772

[11] Rydenm, M. and Arjmand, M. (2012) Continuous Hydrogen Production via the Steam-Iron Reaction by Chemical Looping in a Circulating Fluidized-Bed Reactor. International Journal of Hydrogen Energy, 37, 4843-4854. http://dx.doi.org/10.1016/j.ijhydene.2011.12.037

[12] Frost, B.R. (1985) On the Stability of Sulfides, Oxides, and Native Metals in Serpentinite. Journal of Petrology, 26, 31-63. http://dx.doi.org/10.1093/petrology/26.1.31

[13] McCollom, T.M. (2013) Laboratory Simulations of Abiotic Hydrocarbon Formation in Earth’s Deep Subsurface. Reviews in Minerology and Geochemistry, 75, 467-494. http://dx.doi.org/10.2138/rmg.2013.75.15

[14] Andreani, M., Daniel, I. and Pollet-Villard, M. (2013) Aluminum Speeds up the Hydrothermal Alteration of Olivine. American Mineralogist, 98, 1738-1744. http://dx.doi.org/10.2138/am.2013.4469 
Scientific Research Publishing (SCIRP) is one of the largest Open Access journal publishers. It is currently publishing more than 200 open access, online, peer-reviewed journals covering a wide range of academic disciplines. SCIRP serves the worldwide academic communities and contributes to the progress and application of science with its publication.

Other selected journals from SCIRP are listed as below. Submit your manuscript to us via either submit@scirp.org or Online Submission Portal.
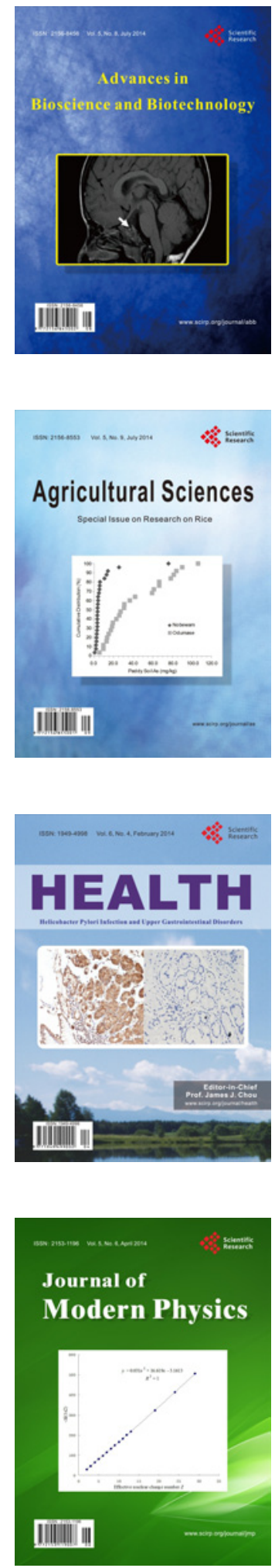
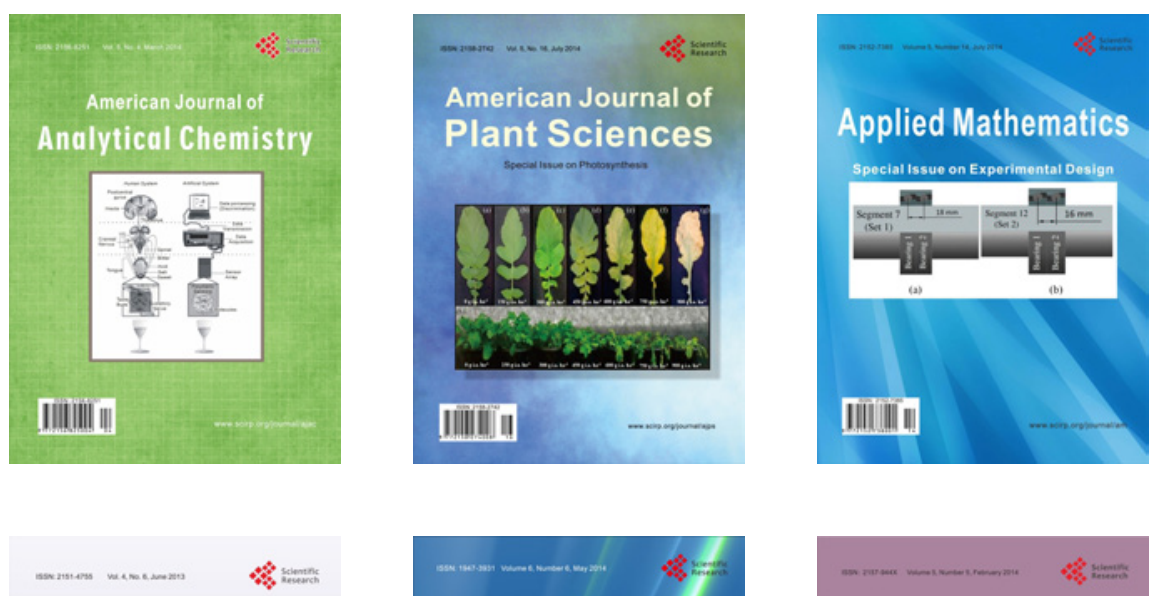

Creative Education
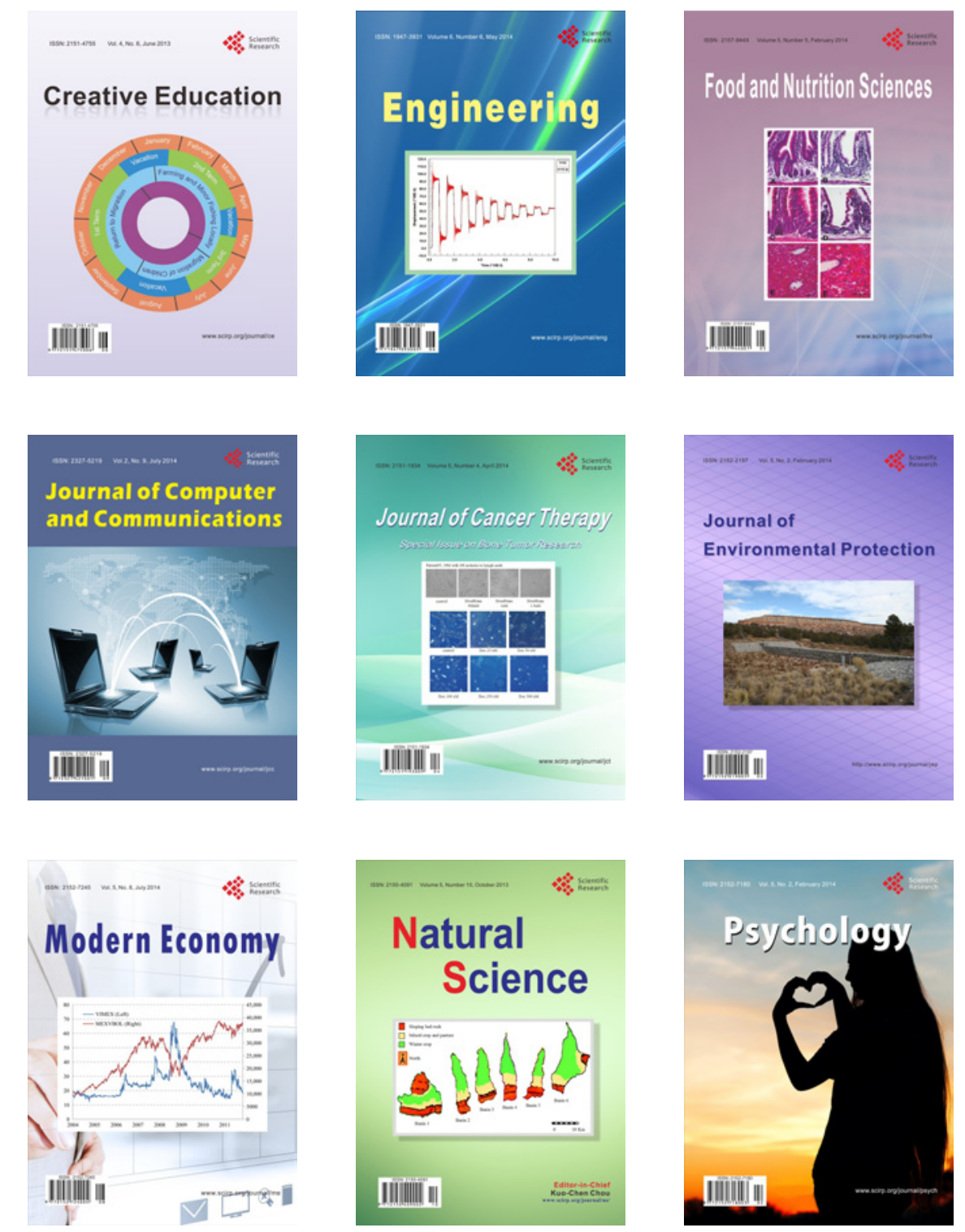